\title{
The Analysis of Reading Skills and Visual Perception Levels of First Grade Turkish Students
}

\author{
Aysel Memiş ${ }^{1}$, Diler Ayvaz Sivri ${ }^{1}$ \\ ${ }^{1}$ Bulent Ecevit University, Ereğli Education Faculty, Kdz.Eregli-Zonguldak, Turkey \\ Correspondence: Assoc. Prof. Dr. Aysel Memiş, Bulent Ecevit University, Ereğli Education Faculty, \\ Kdz.Eregli-Zonguldak, Turkey.
}

Received: June 12, 2016 Accepted: June 27, $2016 \quad$ Online Published: July 21, 2016

doi:10.11114/jets.v4i8.1663 URL: http://dx.doi.org/10.11114/jets.v4i8.1663

\begin{abstract}
In this study, primary school first grade students' reading skills and visual perception levels were investigated. Sample of the study, which was designed with relational scanning model, consisted of 168 first grade students studying at three public primary schools in Kozlu, Zonguldak, in 2013-2014 education year. Students' reading level, reading comprehension, reading errors were determined by "The Informal Reading Inventory", and their visual perception levels were determined with "Developmental Test of Visual Perception-2". Data was coded in SPSS version 22.0. As a result of the study, the majority of students was identified at the level of anxiety while thirty four students was identified at the instructional level, it was also seen that there was no student at an independent level. Instructional level students had higher reading speeds and reading comprehension than anxiety level students significantly. Anxiety level students had higher reading error rates than instructional level students significantly. It was seen that instructional level students having higher reading levels had significantly higher general visual, motor-independent, and visual-motor perception than anxiety level students. While anxiety level students were above average, instructional level students are superior all visual perception abilities.There is a positive meaningful relationship between the all levels of visual perception, and reading speed, reading comprehension. As first grade students' general visual perception, motor-independent visual perception, and visual-motor perception scores increased, reading speed and reading comprehension increased, reading error scores decreased.
\end{abstract}

Keywords: reading level, visual perception, DTVP-2, primary school first grade students

\section{Introduction}

In primary school education, a process of providing fluent and meaningful reading begins after providing them basic reading and writing skills. During primary school years, students are needed to develop reading skills, be able to criticize, discuss, think, associate the things that they read by using their prior knowledge, and obtain new meanings. It is very important to begin education in early childhood years in terms of developing their perception abilities (Çiftçi and Temizyürek, 2008:111). When a child could not learn reading or has dyslexia in spite of not having mental or emotional difficulty, it is beneficial to search psychological processes playing role in reading process. The psychological processes that play role in reading process include visual perception, audio perception, memory, attention, and language skills. A failure of one of those will affect reading negatively (Akçin, 1993:18). The child that is in reading process must have visual perception skills which is appropriate for his age to differentiate written letters, words, and punctuation marks (Duru, 2008:16). It can be said that the children that experience difficulty in visual perception will have difficulty in learning how to read, therefore their academic success will not be in expected levels (Duru, 2008:1). Since learning to read necessitates skills such as perception of spatial relations, figure-ground relation, it is inevitable that first grade students' failures of visual perception directly affects their reading and writing skills. Therefore students that have weak visual perception level make more reading and writing mistakes (Ferah, 2007:104). In their research, Memiş and Harmankaya (2012a) revealed that students who had advanced level general visual perception have lowest error and highest writing scores. It was seen that students having most writing errors had also poor visual perception levels.

Researchers agree that the children that experience perceptual problems and display learning disability can develop severe learning disability and therefore other disorders might appear in the future if their disabilities are not diagnosed and treated well (Sağol, 1998:5). Benveniste (1962) suggested that students should be given visual perceptual and 
reading relation in kindergarten and first grade. As a result, the later the age become, the lower the correlation between visual perception and reading success.

Waugh \& Watson (1970) seems that visual perceptual tests may have some value as predictors of first grade reading achievement. However, above first grade level these tests do not predict reading achievement, and differentiate good from poor readers. Kershner (1975), in an intact class of grade two children, cognitive spatial ability was better than the children's visual-perceptual ability in differentiating good from poorer readers. The results suggest that perceptual-motor training will be the most effective when used preventively rather than remedially and when the programs are implemented during the early years of development at the time the child is in Piaget's preoperational stage. Cheung et all (2006) investigate the visual-perceptual performance of children in Hong Kong by comparing them to the accepted norms on the Developmental Test of Visual Perception-2nd edition. Results indicated that grade differences were found to be significant in all subtests except eye-hand coordination and visual-motor speed. On the other hand, there were no statistical differences in the test scores between boys and girls except on copying and figure-ground subtests. It was concluded that there was a strong need to ensure that norms for visual-perceptual tests were appropriate for the specific cultural groups being assessed. Memiş \& Harmankaya (2012) was aimed to examine the visual perception levels of 185 first grade Turkish students. Students' visual perception levels were determined by means of Turkish version Developmental Test of Visual Perception-2. The results showed that students' visual perception levels were moderate. There was no significant difference between gender and visual perception. However there were significant differences between visual perception levels and parental educational levels, background of story telling by parents during early childhood, early childhood education experience and having reading skill background respectively. There was also significant relationship between students' visual perception levels and academic achievement.

Reading that includes visual perception processes is a considerable complex process. Therefore it is indispensable that visual perception errors affects individual's learning to read, reading, and therefore reading comprehension processes negatively. In first year of education determining children's reading ability, reading skill and visual perceptual level is considered necessary for their post-education life.

The aim of the research is to examine first grade Turkish students' reading skills and visual perception levels. In this direction, some questions were tried to be answered:

1. Do reading speed, reading comprehension, and reading error differentiate in regard to reading level of first grade Turkish students?

2. Do visual perception level differentiate in regard to reading levels of first grade Turkish students?

3. Do visual perception level significantly relate to reading speed, reading comprehension, and reading error of first grade Turkish students?

\section{Method}

\subsection{Research Model}

Relational scanning model was used in this research. The measurements of first grade students' reading abilities and visual perception levels were compared.

\subsection{Research Group}

The population of the research was first grade students, who studied in Zonguldak, Kozlu in 2013-2014 school year. It's sample consisted of 168 first grade students (50\% girl, 50\% boy), who attended three primary schools in district center and selected by purposive sampling.

\subsection{Data Collecting Tools}

The Informal Reading Inventory was used in order to determine students' reading levels, reading comprehension, reading errors, and Developmental Visual Perception Test-2 (DTVP-2) was used to determine their visual perception levels. Students' reading speeds were word number of students when they read per minute, and sound recordings were listened for this purpose.

The Informal Reading Inventory that was adapted to Turkish from Harris and Sipay (1990), Ekwall and Shanker (1988), and May (1986) by Akyol (Quotation Akyol, 2008:92). The aim of the inventory is to determine reader's individual reading level. This inventory tries to determine error rates, vocabulary, and phonetics while oral reading and asks questions to determine comprehension after silent reading. It is also an informative inventory about word recognition and comprehension erros. With this inventory, we determined three reading levels. Independent level (word recognition 99\%, reading comprehension 90\%) means that readers can read appropriate materials and comprehend them without any teacher's or another adult's help. Instructional level (word recognition 90-99\%, reading comprehension 51-89\%) means that readers can only read and comprehend with a teacher's or another adult's help. Anxiety level (word 
recognition under $90 \%$, reading comprehension under 50\%) means that readers can comprehend very little and/or make many mistakes. Two reading texts were selected from first grade level to measure reading errors, reading comprehensions and reading speeds of the students that participated to the research. These texts were narrative texts that students had not read before. Expert opinion was got from two expert academicians and three teachers were adviced in text selection and question preparing. After receiving necessary approvals from the institutions, students' readings were recorded. Related to each text reading, five comprehension questions consisting two simple comprehension questions and three deep comprehension questions were formed. Simple comprehension questions were grouped into recognition and remembering; deep comprehension questions were grouped into inference and interpretation (Akyol, 2013:98-100).

Developmental Visual Perception Test-2, the new form of Frostig Visual Perception Test, was developed by Hammill, Pearson, and Voress in 1993. It is a test used for assessing 4-11 aged children's both visual perception and visual-motor integration skills and is based on updated theories of visual perceptual development (Hammill et al., 1993). Firstly, this test was used in Turkey by Erdem (2006) to determine the relations between 5-6 aged kindergarten children and mathematical skills. By Duru (2008), it was used in 6 aged retarded children to standardize for Turkey and its validity and reliability study was done.

Table 1. DTVP-2 subtest and composite scores

\begin{tabular}{ll}
\hline Composite Scores & No \\
\hline General Visual Perception & $(1+2+3+5+6+7+8)$ \\
Motor-Reduced Visual Perception & $(2+4+6+8)$ \\
Visual-Motor Integration & $(1+3+5+7)$ \\
\hline Subtest & No \\
\hline Eye-Hand Coordination & 1 \\
Position in Space & 2 \\
Copying & 3 \\
Figure-Ground & 4 \\
Spatial Relations & 5 \\
Visual Closure & 6 \\
Visual-Motor Speed & 7 \\
Form Constancy & 8 \\
\hline
\end{tabular}

\subsection{Analysis of Data}

Collected data was coded in SPSS version 22.0. While interpreting data, frequency and percentage distributions that were descriptive statistic techniques were calculated in order to determine general distribution properties. In the research, t-test, and Pearson product-moment correlation coefficient were used because of normal distribution. In statistical analysis and interpretation, $p<0.01$ level was considered significant.

\section{Findings}

\subsection{Reading Level, and Reading Speed, Reading Comprehension, Reading Errors}

Table 2. Reading level of first grade students $(\mathrm{N}=168)$

\begin{tabular}{llll}
\hline & \multicolumn{1}{c}{$\mathbf{N}$} & \% \\
\hline Anxiety Level & 134 & 79.8 & \\
Instructional Level & 34 & 20.2 & \\
Independent Level & - & - & \\
\hline Total & 168 & 100.0 \\
\hline
\end{tabular}

$79.8 \%$ of first grade students was in anxiety level, $20.2 \%$ of them was in instructional level, while none of them was independent level in application time because they were only first grade students.

Table 3. Reading level and reading speed, reading comprehension, reading errors $(\mathrm{N}=168)$

\begin{tabular}{|c|c|c|c|c|}
\hline Reading Speed & $\mathbf{N}$ & $\mathbf{M}$ & $\mathbf{S}$ & $\mathbf{t}$ \\
\hline Anxiety level & 134 & 39.34 & 13.58 & \multirow{2}{*}{$-6.447 *$} \\
\hline Instructional level & 34 & 56.03 & 13.02 & \\
\hline Reading Comprehension & $\mathbf{N}$ & M & $\mathbf{S}$ & $\mathbf{t}$ \\
\hline Anxiety level & 134 & 45.38 & 22.89 & \multirow[t]{2}{*}{$-12.685^{*}$} \\
\hline Instructional level & 34 & 80.91 & 11.56 & \\
\hline Reading Errors & $\mathbf{N}$ & M & $\mathbf{S}$ & $\mathbf{t}$ \\
\hline Anxiety level & 134 & 11.31 & 10.87 & \multirow{2}{*}{$8.600 *$} \\
\hline Instructional level & 34 & 2.85 & 1.69 & \\
\hline
\end{tabular}

${ }^{*} p<0.01$

Instructional level students had higher reading speeds and reading comprehension than anxiety level students significantly. Anxiety level students had higher reading error rates than instructional level students significantly. 


\subsection{Reading Level and Visual Perception}

Table 4. Reading level and visual perception

\begin{tabular}{|c|c|c|c|c|}
\hline General Visual Perception & $\mathbf{N}$ & $\overline{\mathbf{X}}$ & $\mathbf{S}$ & $\mathbf{t}$ \\
\hline $\begin{array}{l}\text { Anxiety Level } \\
\text { Instructional Level }\end{array}$ & $\begin{array}{l}134 \\
34\end{array}$ & $\begin{array}{l}112.39 \\
126.61\end{array}$ & $\begin{array}{l}12.80 \\
10.42\end{array}$ & $-5.987 *$ \\
\hline Motor-Independent Visual Perception & $\mathbf{N}$ & $\overline{\mathbf{X}}$ & $\mathbf{S}$ & $\mathbf{t}$ \\
\hline $\begin{array}{l}\text { Anxiety Level } \\
\text { Instructional Level }\end{array}$ & $\begin{array}{l}134 \\
34\end{array}$ & $\begin{array}{l}113.23 \\
123.29 \\
\end{array}$ & $\begin{array}{l}13.56 \\
11.51 \\
\end{array}$ & $-3.972 *$ \\
\hline Visual-motor Perception & $\mathbf{N}$ & $\overline{\mathbf{X}}$ & $\mathbf{S}$ & $\mathbf{t}$ \\
\hline $\begin{array}{l}\text { Anxiety Level } \\
\text { Instructional Level }\end{array}$ & $\begin{array}{l}134 \\
34\end{array}$ & $\begin{array}{l}109.85 \\
127.35 \\
\end{array}$ & $\begin{array}{l}16.96 \\
12.52 \\
\end{array}$ & $-5.632 *$ \\
\hline
\end{tabular}

$*_{p}<0.01$

In Table 4 it can be seen that instructional level students having higher reading levels had significantly higher general visual, motor-independent, and visual-motor perception than anxiety level students $(p<.01)$. While anxiety level students were above average, instructional level students were superior all visual perception abilities.

\subsection{Visual Perception, and Reading Speed, Reading Comprehension, Reading Errors ( $N=168$ )}

Table 5. Visual perception, and reading speed, reading comprehension, reading errors

\begin{tabular}{|c|c|c|c|c|}
\hline & & $\begin{array}{l}\text { Reading } \\
\text { Speed }\end{array}$ & $\begin{array}{l}\text { Reading } \\
\text { Comprehension }\end{array}$ & $\begin{array}{l}\text { Reading } \\
\text { Errors }\end{array}$ \\
\hline General Visual Perception & & $.479 *$ & $.493^{*}$ & $-.416^{*}$ \\
\hline $\begin{array}{l}\text { Motor-Reduced } \\
\text { Perception }\end{array}$ & Visual & $.377^{*}$ & $.381^{*}$ & $-.408^{*}$ \\
\hline Visual-Motor Integration & & $.454^{*}$ & $.469^{*}$ & $-.418^{*}$ \\
\hline
\end{tabular}

$*_{p}<0.01$

There was a positive meaningful relationship between the all levels of visual perception, and reading speed, reading comprehension $(p<0.01)$. As first grade students' general visual perception, motor-independent visual perception, and visual-motor perception scores increased, reading speed and reading comprehension increased, while reading error scores decreased.

\section{Discussion}

As a result of the study done in late months of the first grade, it was seen that most students' reading levels were in anxiety level and $20 \%$ students' reading levels were in instructional level. In the period that we performed application in first grade students, there was no student in independent level.

It was found that the students that had instructional level reading level had significantly higher than anxiety level students for all levels of visual perception. While anxiety level students were above average in general perception and its sub-dimensions, instructional level students were superior. Thus it can be said that students having good reading level also have higher visual perception. Benveniste (1962), Richardson (1981), Kavale (1982), Delcamp (1983), and Akçin (1993) support this result. Thompson (1975) revealed that there is significant relation between visual perception levels and year-end reading success. Similarly, Shellenberg (1962) found significant difference between reading scores and visual-motor perception scores of third grade students, who were classified into sufficient and insufficient readers.

Kayhan (2010) determined that as error score of visual perception tests increases reading comprehension scores decreases and Baş and Kardaş's (2014), in which they determined that scores of fourth grade students obtained from reading comprehension test was significantly related to visual reading test scores. Wright (1976) revealed that intellectual and visual-motor variables were more closely related to reading achievement. Kavale and Forness (2000) investigated the relationship between auditory and visual perception and reading achievement. The findings indicated that auditory and visual perceptual skills can successfully increase the accuracy of predicting reading achievement. It was concluded that, while there was some justification for early conceptualizations of learning disability emphasizing perception, the limitations surrounding the magnitude and nature of the relationship between perceptual skills and reading as well as recent advances showing other processes holding greater promise for explaining reading disability, perceptual processes no longer need to be considered primary factors in predicting reading ability. According to Akçin (1993) the development of visual perception has an impact on acquiring reading skills. The students with low visual sensitiveness test grades are expected to have many dictation mistakes. The students who attended pre-school education obtained slightly higher points in visual sensitiveness test than the students who did not attend pre-school education 
(Ferah, 1996). Arıkök (2001) claimed that a child's reading readiness is directly affected by his / her visual perception level. In this study there was positively correlation between reading speed and reading comprehension considering visual perception level. As first grade students' general visual perception, motor-independent visual perception, and visual-motor perception abilities increased, reading speed and reading comprehension increased too, on the other hand reading error scores decreased.

\section{Recommendations;}

* Reading skills failure of students also affects their success in other courses negatively. Therefore teachers should prepare activities aiming students' reading development in early school years.

* When their children are in pre-school period, parents should buy visual materials such as books, magazines, and newspapers that contain plenty of images, read them to their children, and ask their children to examine these materials. Beginning from the first grade, children can develop their visual perception and reading skills by reading and examining written materials with their parents.

\section{References}

Akçin, N. (1993). Okuma becerisinin kazanılmasında görsel algisal gelişsiminin rolü (Unpublished master's thesis). Hacettepe Üniversitesi, Ankara, Turkey.

Akyol, H. (2008). Yeni programa uygun türkçe öğretim yöntemleri. Ankara: Kök Yayıncılık.

Akyol, H. (2013). Türkçe ögretim yöntemleri.Ankara:Pegem Akademi Yayıncıllk.

Arıkök, İ. (2001). Beş-altı yaş çocuklarında görsel algı eğitiminin okuma olgunluğuna olan etkisinin incelenmesi (Unpublished master's thesis).Gazi Üniversitesi, Ankara.

Baş, Ö., \& Kardaş, N. (2014). İlköğretim öğrencilerinin görsel okuma becerisi ile okuduğunu anlama becerisi arasındaki ilişkinin incelenmesi. Uşak Üniversitesi Sosyal Bilimler Dergisi, 7(1), 230-243.

Benveniste, J. (1962). The relative importance of visual perception and intelligence to reading success in kindergarden though third grade (Unpublished master's thesis). The Faculty of the School of Education University of Southern California.

Cheung, P., Poon, M., Leung, M., \& Wong, R. (2006). The developmental test of visual perception-2 normative study on the visual perceptual function for children in Hong Kong, Physical \& Occupational Theraphy in Pediatrics, 25(4), 29-43. http://dx.doi.org/10.1080/J006v25n04_03

Çiftçi, Ö., \& Temizyürek, F. (2008). İlköğretim 5. Sınıf öğrencilerinin okuduğunu anlama becerilerinin ölçülmesi. Mustafa Kemal Üniversitesi Sosyal Bilimler Enstitüsü Dergisi, 5(9), 109-129.

Delcamp, L. N. (1983). Relationships among conservation abilities, auditory and visual perception skillis and school achievement of first grade students (Unpublished master's thesis). University Of Florida.

Duru, H. (2008). Gelişimsel görsel algı testi-2'nin 6 yaş çocukları için güvenirlik ve geçerlik ön çalışması (Unpublished master's thesis). Marmara Üniversitesi, İstanbul, Turkey.

Erdem, M. (2006). Anaokuluna devam eden beş-altı yaş çocukların matematiksel becerileri ile görsel algı becerilerinin karşılaştırlması (Unpublished master's thesis). Hacettepe Üniversitesi, Ankara, Turkey.

Ferah, A. (1996). Illk okuma-yazma öğretiminde görsel algılama ve zekânın yeri (Unpublished master's thesis). Marmara Üniversitesi, İstanbul,Turkey.

Ferah, A. (2007). Türkçe ilk okuma yazmayı öğrenme. Ankara.: Nobel Yayın Dağıtım.

Hammill, D. D., Pearson, N. A., \& Voress, J. K. (1993). Developmental test of visual perception-2nd ed.: examiner's manual. Texas: Pro-Ed. Pub.

Kavale, K. (1982). Meta-analysis of the relationship between visual perceptual skills and reading achievement. Journal of Learning Disabilities, 15, 42-51. http://dx.doi.org/10.1177/002221948201500110

Kavale, K., \& Forness, S. (2000). Auditory and visual perception processes and reading ability: a quantitative reanalysis and historical interpretation. Learning Disability Quarterly, 23, 253-270. http://dx.doi.org/10.2307/1511348

Kayhan, E. Ö. (2010). İlköğretim birinci kademe çocuklarında okuduğunu anlama ile sözcük bilgisi, görsel algı ve kısa süreli bellek arasındaki ilişki (Unpublished master's thesis). Ankara Üniversitesi, Ankara, Turkey.

Kershner, J. R. (1975). Visual-spatial organization and reading: support for a cognitive-developmental interpretation Journal of Learning Disabilities, 8, 30-36. http://dx.doi.org/10.1177/002221947500800109

Memiş, A., \& Harmankaya, T. (2012). İlköğretim okulu birinci sınıf öğrencilerinin görsel algı düzeyleri. Türkiye Sosyal Araşttrmalar Dergisi, 16(1), 27-46. 
Memiş, A., \& Harmankaya, T. (2012a). İlköğretim okulu birinci sınıf öğrencilerinin bitişik eğik el yazısı hataları ile görsel algı düzeylerinin incelenmesi. Dicle Üniversitesi Ziya Gökalp Eğitim Fakültesi Dergisi, 19, 136-150.

Richardson, K. M. (1981). The relationship of selected visual perception abilities to the reading achievement of first grade students (Unpublished doctoral dissertation). Temple University.

Sağol, U. (1998). Down Sendromlu çocukların görsel algı gelişimine frostig görsel algı programının etkisi (Unpublished master's thesis). Marmara Üniversitesi, İstanbul,Turkey.

Shellenberg, E. D. (1962). A study of the between visual-motor process and reading disabilities of third grade pupils (Unpublished doctoral dissertation). University of Southern California.

Thompson, L. J. J. (1975). The relationship of visual perception to reading achievement and the effects of two types of visual perceptual training on reading achievement in the first-grade year (Unpublished doctoral dissertation). University of Southern Mississippi.

Waugh, R., \& Watson, Z. (1970). Visual perception and reading. Education, 91(2), 181-184.

Wright, J. A. (1976). Relation of visual and motor perception to reading achievement among children with one year of study in school (Unpublished doctoral dissertation). Ohio State University.

This work is licensed under a Creative Commons Attribution 3.0 License. 